8. Рысин Л.П., Мозолевская Е.Г., Савельева Л.И. Влияние рекреации на лесные экосистемы и их компоненты. Пущино: Изд-во ОНТИ ПНЦ РАН, 2004. $302 \mathrm{c}$.

9. Рысин Л.П., Рысин С.Л. Урболесоведение. М.: Товарищество научных изданий КМК, 2012. 240 с.

10. Сальников А.Л., Пилипенко В.Н. Антропогенная трансформация флоры города Астрахани и его окрестностей за последние 100 лет // Экология. 2005. № 6. С. 421-428.

11. Савельева Л.И. Динамика и устойчивость древостоев сложных сообществ в рекреационных лесах ближнего Подмосковья // Актуальные проблемы рекреационного лесопользования: мат-лы междунар. науч. конф. М.: КМК, 2007. С. 22-24.

12. Степанов М.В. Рекреационная трансформация пригородных лесов Саратова: дис. ... канд. биол. наук: 03.00.16. Саратов, 2002. 237 с.

13. Хайретдинов А.Ф., Конашова С.И. Рекреационное лесоводство: учеб. пособие для студентов вузов, обучающихся по специальности 260400 «Лесное хозяйство». М.: Изд-во МГУЛ, 2002. 308 с.

14. Чижова В.П., Прыгунова И.Л. Рекреация и заповедное дело: Итоги и перспективы взаимодей- ствия: учебное пособие. Минск: ДОЛ-принт, 2004. $120 \mathrm{c}$.

15. Рысин Л.П., Абатуров А.В., Савельева Л.И., Меланхолин П.Н., Полякова Г.А., Рысин С.Л. Динамика и устойчивость рекреационных лесов. М.: КМК, 2006. 165 c.

16. Рысин С.Л., Лепешкин Е.А. Опыт оценки рекреационного потенциала лесов на урбанизированных территориях // Лесные экосистемы и урбанизация: сборник статей. М.: КМК, 2008. С. 183-208.

17. Тумуреева Н.Н. Методический подход к оценке рекреационного потенциала на территории Республики Бурятия // Вестник Бурятского государственного университета. Биология. География. 2007. № 3. С. $81-84$.

18. Алексеев В.А. Диагностика жизненного состояния деревьев и древостоев // Лесоведение. 1989. № 4. С. 51-57.

19. Байчибаева А.В. Оценка рекреационного влияния на почвы Природного парка «Оленьи ручьи» // Аграрный вестник Урала. 2011. № 4 (83). С. 55-56.

20. Рожков Л.Н. Основы теории и практики рекреационного лесоводства: монография. Минск: Издво Белорус. гос. технолог. ун-та, 2001. 212 с.

\title{
GRADE OF RECREATIONAL POTENTIAL OF SAMARA SUBURBAN FORESTS
}

Kazantsev Ivan Victorovich, candidate of biological sciences, associate professor of Chair of Chemistry, Geography and Methods of Teaching, dean of Faculty of Natural Sciences and Geography

Matveeva Tatyana Borisovna, candidate of biological sciences, associate professor of Chair of Biology, Ecology and Methods of Teaching Samara State University of Social Sciences and Education (Samara, Russian Federation)

Abstract. Authors provide materials in article revealing recreational potential of Samara suburban forests and use S.L. Rysin's technique, which considers a sanitary condition of the woods, extent of recreational transformation and esthetic importance of forest plantings in article. Researchers counted coefficients of appeal, comfort and stability of forest communities for carrying out complex assessment. On their basis authors judge quality of the surveyed forests. They have obtained materials of vital state are submitted and values of water penetration of the soil. This indicator of recreational disturbance is important for forest communities. For this reason, researchers considered different in degree of a recreational digression. Researchers have conducted a research and have revealed that appeal and comfort high and stability is average in Samara suburban forests. Therefore, experts have to hold complex of actions, which improve a condition of forest plantings and increasing their stability in the conditions of anthropogenic loading. These materials allow defining condition of Samara suburban forests and their suitability for use in the recreational and tourist purposes.

Keywords: suburban forests; technogenic influence; stability of woods; anthropogenic transformation; recreation; recreational potential; recreational digression; stages of digression; track network; appeal; comfort; stability; vital condition of forest stands; water penetration of soil.

УДК 598.272.6

Статья поступила в редакцию 20.06.2018

\section{ВИДОВОЙ СОСТАВ И ЧИСЛЕННОСТЬ ДЯТЛОВ (РICIDAE) В ЧУВАШСКОМ ЗАВОЛЖЬЕ В ЗИМНИЙ ПЕРИОД}

(C) 2018

Коленов Сергей Евгеньевич, аспирант, инженер кафедры зоологии и общей биологии

Казанский (Приволжский) федеральньий университет (2. Казань, Российская Федераџия)

Аннотация. В данной статье приводятся данные о зимней фауне дятлов (Рicidae) Заволжья Чувашской Республики. Анализируется видовой состав, численность и тенденции ее изменения. Выводы делаются на основе материалов, собранных в 2010-2018 годах на трех маршрутах в ходе орнитологических учетов по стандартной методике Ю.С. Равкина. Актуальность работы заключается в том, что в Чувашском Заволжье подобные систематические исследования зимней фауны дятлов ранее не проводились. Также она позволяет определить, какое воздействие на орнитофауну Заволжья оказали разрушительные пожары лета 2010 года, уничтожившие до $30 \%$ лесного покрова исследуемой территории. Согласно нашим выводам, Чувашское За- 
волжье населяют 6 видов дятлов из 9, отмеченных в Чувашской Республике. Из них большой пестрый дятел относится к многочисленным и доминирующим видам, желна - к обычным, а остальные встречались реже. Наибольшее разнообразие дятлов было отмечено на маршруте с максимальным разнообразием растительности и большим количеством сухостоя. Достоверный положительный тренд численности был выявлен для желны. Численность большого пестрого дятла в целом оставалась стабильной, хотя и демонстрировала значительные колебания от года к году (вероятно, в зависимости от урожайности хвойных деревьев). Для остальных видов выявить какой-либо многолетний тренд не удалось. Для трех видов дятлов - желны, малого пестрого и трехпалого дятлов - обнаружены сходные тенденции средней зимней плотности. Все эти виды демонстрировали значительный рост численности, который затем сменился снижением. Полагаем, что рост численности обеспечили пожары и засуха 2010 года, спровоцировавшие вспышку насекомых-ксилофагов, кормовой базы этих видов. Последовавшая расчистка горельников и санитарные рубки сократили доступные для насекомых пищевые ресурсы, что, в свою очередь, привело к снижению численности дятлов. Считаем, что для сохранения этих видов необходимо отказаться от санитарных рубок на некоторых участках Заволжья.

Ключевые слова: дятлы; Дятлообразные; большой пестрый дятел; желна; трехпалый дятел; малый пестрый дятел; седой дятел; белоспинный дятел; зеленый дятел; средний пестрый дятел; вертишейка; зимнее население птиц; динамика численности птиц; экология; хвойные леса; Чувашская Республика; Чебоксарский район; Поволжье; Чувашское Заволжье; пожары.

\section{Введение}

Дятлы (Picidae) - широко распространенная группа птиц, представители которой в основном населяют леса. Они не только специализированы к жизни в лесных экосистемах, но и являются в них средообразующими видами, которые регулируют численность насекомых-вредителей и создают дупла, используемые другими видами птиц и млекопитающих. Все это делает дятлов важным объектом экологических исследований и индикатором состояния лесов [1, p. 83].

Российскую Федерацию населяют 13 видов дятлов [2, с. 338; 3, с. 282-435]. Из них на территории Чувашской Республики отмечены 9 видов [4, с. 273]. Большинство их них обычны, однако некоторые относятся к редким и залетным. Дятлам Чувашии посвящен ряд орнитологических исследований; наиболее полный обзор современной численности и особенностей биологии этих птиц в регионе сделан во втором томе монографии «Птицы Чувашии» [4, c. 272-295]. Что касается зимней фауны, то она в течение многих лет исследовалась в ходе программы «Рarus» на территории заповедника «Присурский» и национального парка «Чӑваш вӑрманӗ» [5, с. 81-83]. В других частях Чувашии подобные исследования были несистематическими или не проводились.

В частности, в сводке «Птицы Чувашии» очень слабо представлены данные о дятлах, населяющих Чувашское Заволжье - участок территории республики, расположенный на левом берегу реки Волга (Чебоксарского водохранилища). При этом Заволжье, покрытое хвойным лесом и относительно слабо освоенное человеком, является важным местом обитания для многих представителей семейства дятловых и других лесных птиц. Кроме того, после пожаров 2010 года [6, с. 79] эта территория претерпела значительные экологические изменения, и важно отследить, как они отразились на орнитофауне.

\section{Цель и объекты исследования}

В данной работе мы ставим перед собой цель определить видовой состав дятлов Чувашского Заволжья, дать оценку численности разных видов и выявить ее тенденции в течение исследованного периода. Также мы проводим сравнение наших данных с информацией, полученной из литературных источников.

\section{Район исследований}

Чувашское Заволжье - единственный участок территории Чувашской Республики, лежащий на левом берегу реки Волга (Чебоксарского водохранилища). Хозяйственная деятельность человека здесь развита слабо, несмотря на наличие нескольких поселков, санаториев и баз отдыха. В административном отношении территория относится к Чебоксарскому району Чувашской Республики.

С точки зрения физико-географического районирования Заволжье входит в Ветлужско-Кокшагский полесский район провинции южной тайги и смешанных лесов низменного Поволжья [7, с. 63]. Естественный растительный покров, характерный для исследованной территории, - хвойные леса, в которых доминирует сосна обыкновенная (Pinus sylvestris L.) [8, с. 10]. Среди других массовых древесных пород здесь произрастают береза повислая (Betula pendula Roth.) и ель обыкновенная (Picea abies (L.) Karst.). На пойменных участках преобладают осина (Populus tremula L.) и ольха черная (Alnus glitinosa (L.) Gaertn.). Пожары лета 2010 года привели к уничтожению примерно трети лесного покрова Заволжья, в основном в северной части [9, с. 79], в настоящее время эти горельники расчищены от сухостоя и зарастают [10, с. $80-81]$.

Исследования проводились нами на трех учетных маршрутах, которые проходят по участкам Заволжья, отличающимся друг от друга по ряду характеристик (рис. 1).

Протяженность маршрута «Росинка» составляла 7 км, от озера Астраханка до санатория «Чувашия». Из всех исследованных участков данный испытывает наиболее сильное антропогенное воздействие: здесь расположено несколько баз отдыха, а лес регулярно посещается людьми, даже в зимнее время. Также маршрут пересекает асфальтированная дорога «Чебоксары-Сосновка». Для территории характерно значительное количество подроста и сухих деревьев, а также разреженный древостой. Участок частично входит в состав природного заказника «Заволжский» [11].

Маршрут «Сосновка» проходит вдоль берега p. Волга, к западу от поселка Первомайский. Его длина равна 8 км. Для участка характерно незначительное количество подроста и участки пойменного леса из ольхи и осины. Антропогенное влияние на территорию умеренное. 
Длина маршрута «Ландыш» составляет 8 км. Участок, по которому он проходит, расположен к западу от участка «Сосновка» и граничит с базой от- дыха «Ландыш». Он наиболее удален от речного берега и практически не посещается людьми. Для древостоя характерна высокая доля ели.

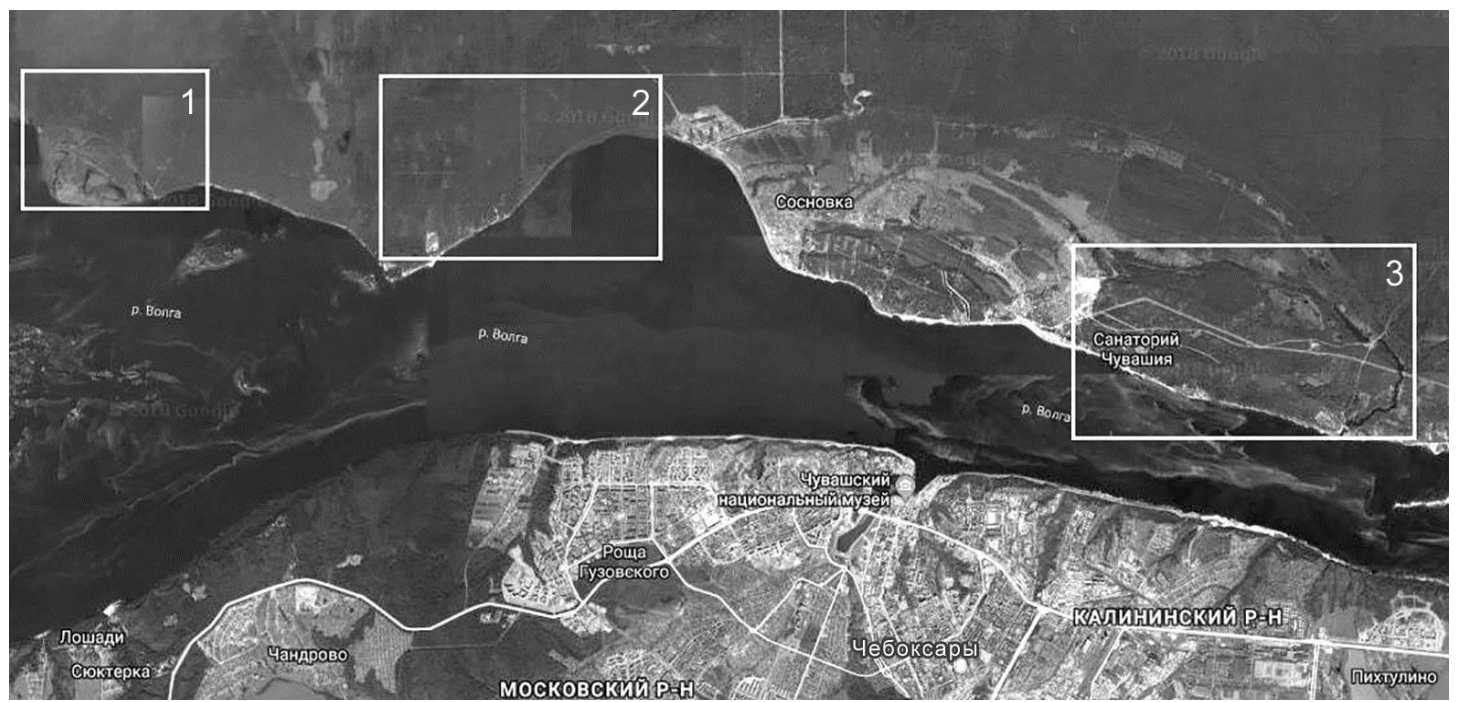

Рисунок 1 - территория Заволжья с отмеченными на нем участками, на которых проводились исследования: 1 - «Ландыш», 2- «Сосновка», 3- «Росинка»

\section{Материалы}

\section{и методика исследований}

В основу работы легли данные о численности и разнообразии дятлов, собранные нами с 2010 по 2018 год на территории Заволжья Чувашской Республики. Исследования проводились с помощью маршрутного метода учета без фиксированной полосы по Ю.С. Равкину [12, с. 67-75]. Сбор информации проходил с ноября по март на трех постоянных маршрутах длиной 7-8 км (см. выше). На маршруте «Росинка» учеты проводились 1 раз в две недели с 2010 по 2014 год, а затем - 1 раз в месяц. На маршрутах «Сосновка» и «Ландыш» учеты велись с периодичностью 1 раз в месяц, с ноября 2014 и 2015 года соответственно.

Статистическая обработка данных производилась с помощью программы Past 2.12. Русские и латинские названия птиц, а также их порядок цитируются по «Списку птиц Российской Федерации» [13, c. 136-139].

\section{Результаты исследований и их обсуждение}

За время исследований на территории Заволжья нами в зимний период отмечено присутствие 6 видов дятлов. Это составляет $67 \%$ от общего видового разнообразия семейства в Чувашской Республике. Из трех оставшихся видов два - зеленый дятел (Picus viridis Linnaeus, 1758) и средний пестрый дятел (Dendrocopos medius Linnaeus, 1758) - не характерны для хвойных лесов и никогда не отмечались в Чувашском Заволжье (сообщение Калашниковой о находке среднего пестрого дятла у озера Большое Лебединое [14, с. 123], вероятно, следует считать ошибкой). Вертишейка (Jynx torquilla Linnaeus, 1758) в летний период населяет исследованную территорию, но относится к перелетным видам и покидает Чувашию уже в августе-сентябре [4, с. 274-275].

Максимальное число видов дятлов было отмечено нами на участке «Росинка» (6), а минимальное на участке «Ландыш» (4). Эти отличия можно свя- зать с тем, что для маршрута «Росинка» были характерны более разнообразные экологические условия и большее количество сухих и усыхающих деревьев, служащих кормовой базой для насекомых.

Далее мы рассмотрим численность конкретных видов и ее динамику в течение периода исследования.

Седой дятел (Picus canus J.F. Gmelin, 1788). Coгласно «Списку птиц Чувашии», в регионе седой дятел является малочисленным гнездящимся оседлым видом [15, с.68]. При этом авторы монографии «Птицы Чувашии» не упоминают ни одной встречи седого дятла на территории Заволжья [4, с. 280-281].

Мы регулярно отмечали седых дятлов на исследованной территории в зимние периоды 20102018 годов. При этом их плотность была невелика, вид относился к малочисленным. На участке «Сосновка» седой дятел был встречен нами 5 раз: в ноябpe 2014, 2015 и 2016 года, а также в марте и ноябре 2017 года. Обилие вида колебалось от 0,4 до 6 ос./км². На маршруте «Росинка» седой дятел встречался чаще: нами зафиксированы 12 встреч с 2010 по 2018 год. В 2010-2015 годах седой дятел регистрировался по одному разу за зимний период, однако затем частота встреч выросла. Средняя численность за исследованный период составила 0,6 ос./км². Анализ численности седого дятла за восьмилетний период не выявил достоверного тренда.

Желна (Dryocopus martius Linnaeus, 1758). Coгласно литературным данным, этот вид в Чувашии относится к малочисленным оседлым [15, с. 68]. Желна занесена в Красную книгу Чувашской Республики под II категорией (редкий вид) [16, с. 238-239].

Согласно нашим наблюдениям, в зимний период 2010-2018 годов желна была обычным видов на территории Заволжья. По численности и частоте встреч этот вид уступал только большому пестрому дятлу. Отметим, что авторы монографии «Птицы Чувашии» также указывают на обычность вида на территории Заволжья, однако единственная оценка численности относится к маю 1986 года $(3,75$ пары на км²); также 
отмечается факт гнездования желны 26.05.2017 [4, c. 282-283].

Мы регулярно отмечали данный вид на всех трех исследованных маршрутах. Наиболее многочисленной желна была на участке «Росинка»: здесь ее среднее обилие в зимние периоды 2015-2018 годов составило 3 ос./км². На маршрутах «Ландыш» и «Сосновка» средняя плотность желны за тот же период составила 1 ос./км². Однако достоверных различий в обилии вида на трех участках обнаружено не было.
Анализ данных о зимней численности желны на участке «Росинка» в 2010-2018 годах показал, что обилие вида здесь достоверно росло ( $\mathrm{r}=0,3$; $\mathrm{p}=0,03)$. С начала периода наблюдений и до 20132014 года обилие желны в зимний период уверенно возрастало, достигнув пика зимой 2013-2014 года, когда средняя плотность составила 6 ос./км² (рис. 2). После этого обилие вида постепенно снижалось, однако общая тенденция за весь исследованный период оставалась положительной.

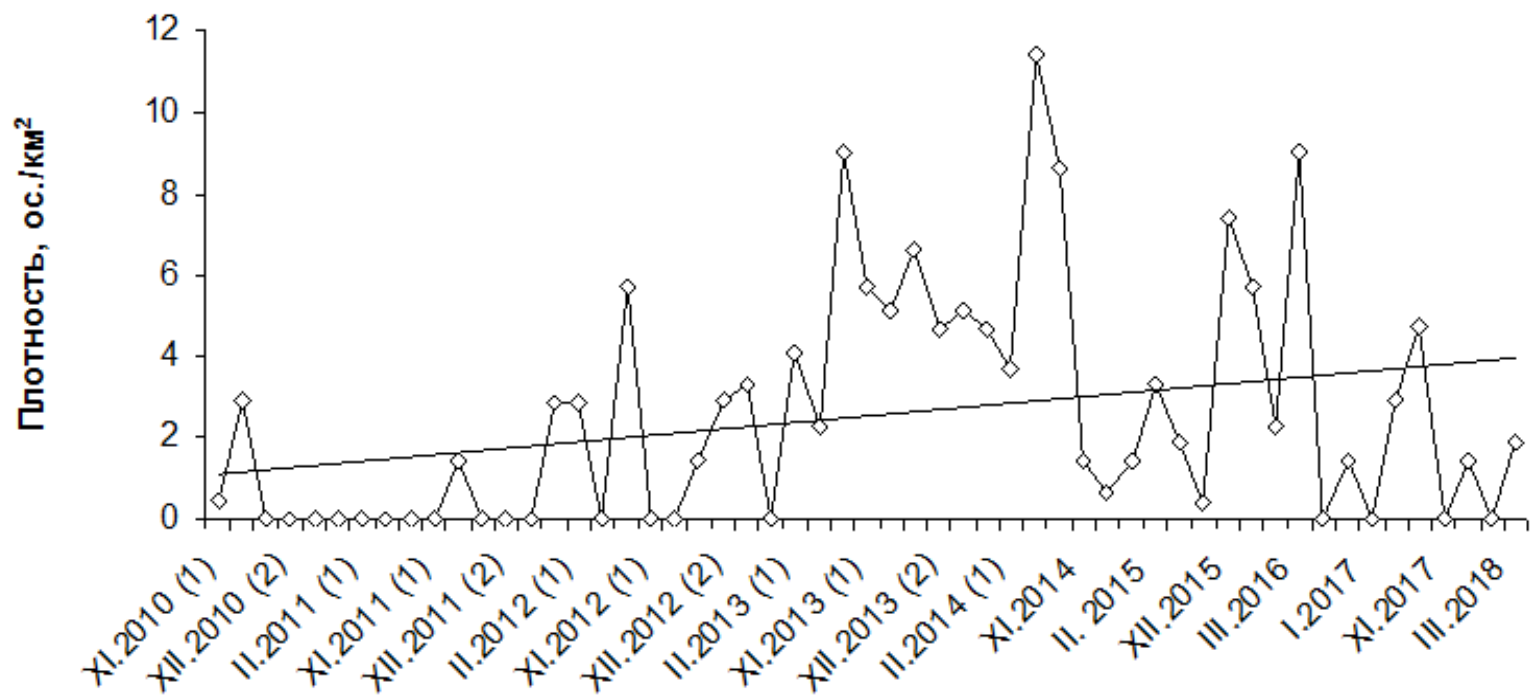

Рисунок 2 - Динамика плотности желны на участке «Росинка» в зимние периоды 2010-2018 гг.

Мы полагаем, что численность желны, специалиста по питанию насекомыми-ксилофагами, отреагировала ростом на пожары и засуху лета 2010 года, которые привели к возникновению обширных горельников на севере чувашского Заволжья и усыханию деревьев на маршруте «Росинка». Дальнейшее снижение обилия было связано с санитарными рубками и расчисткой гарей. Более подробно мы обсуждаем этот механизм ниже, в разделе о трехпалом дятле, для которого указанная тенденция была выражена еще ярче. Статистический анализ выявил достоверную корреляцию средней зимней плотности между желной и малым пестрым дятлом $(\mathrm{r}=0,75$;

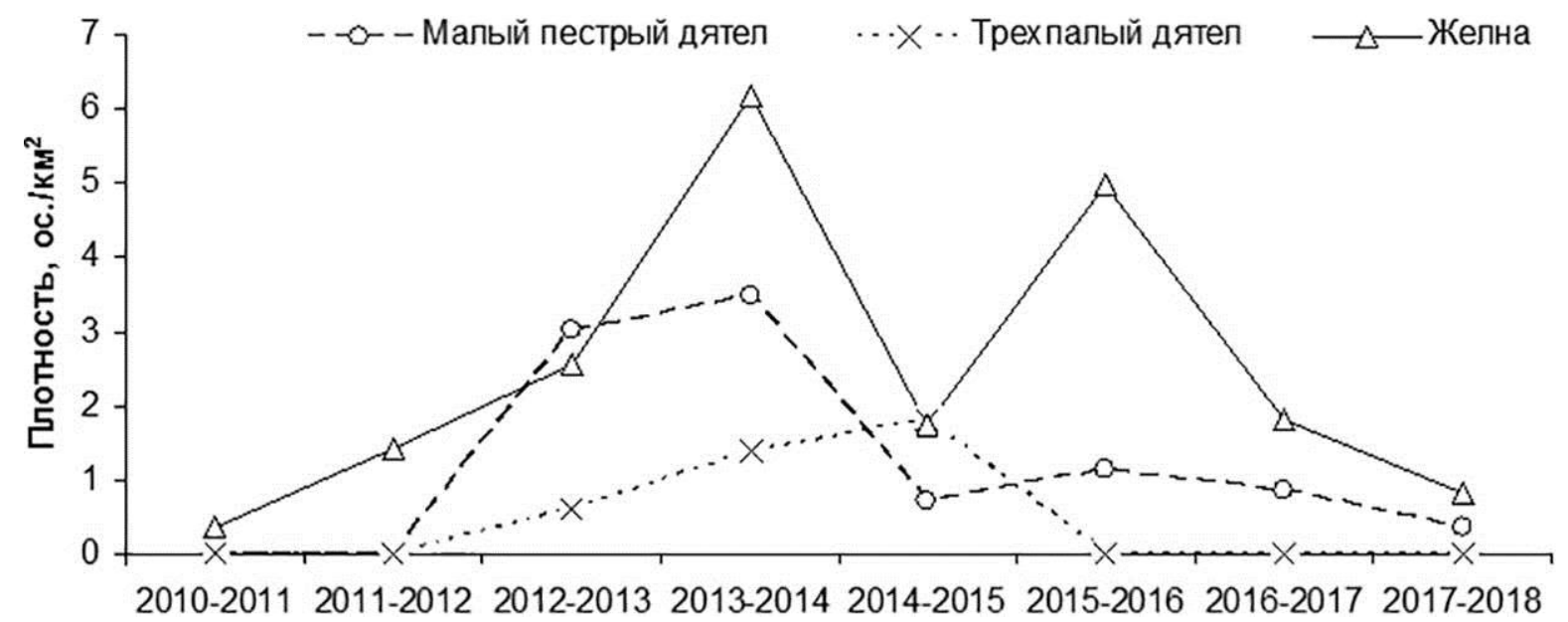

Рисунок 3 - Динамика средней зимней плотности малого пестрого дятла, трехпалого дятла и желны

Большой пестрый дятел (Dendrocopos major Linnaeus, 1758). Согласно литературным данным, этот вид в Чувашии относится к многочисленным оседлым $[15$, с. 68$]$ и населяет различные типы лесов. В Заволжье оценки его зимней численности прово- $\mathrm{p}=0,03)$, а также недостоверную - между желной и трехпалым дятлом $(\mathrm{r}=0,5 ; \mathrm{p}=0,37)$ (рис. 3 ).

Наши оценки обилия желны в Заволжье совпадают или превышают те, что были получены в ходе исследований зимней численности вида в хвойных лесах заповедника «Присурский» и сухих сосняках национального парка «Чӑваш вӑрманӗ». В Присурье зимой 20002005 гг. обилие желны колебалось от 0,3 до 1 ос./км ${ }^{2}$ [17, с. 43-44; 18, с. 42-44]. В национальном парке зимняя плотность вида составила 0,8 ос./км² в 2006/2007 г. и 1,1 ос./км ${ }^{2}$ - в 2007/2008 году [19, с. 33-34; 20, с. 35]. Как и мы, Е.С. Преображенская в Нижнем Присурье отмечает небольшой рост численности желны [5, с. 81].

… . . Трехпалый дятел $\longrightarrow$ Желна дились несколько раз, позднейшая из них - в январе 2006 года [4, с. 285].

Согласно нашим наблюдениям, численность большого пестрого дятла в Заволжье зимой 20102018 годов была высокой. На данной территории он 
был самым многочисленным видом дятлов. Вид отмечался нами на всех трех исследованных маршрутах. Наибольшее обилие большого пестрого дятла зимой 2015-2018 годов было отмечено нами для участка «Росинка». Здесь его плотность была достоверно выше, чем на участках «Ландыш» $(\mathrm{r}=7,25$; $\mathrm{p}<0,01)$ и «Сосновка» $(\mathrm{t}=5,7 ; \mathrm{p}<0,01)$ и составила 69 ос./км². На участках «Ландыш» и «Сосновка» среднее обилие за 2015-2018 годы составило соответственно 30 и 32 ос./км².

Анализ данных, собранных на маршруте «Росинка» в 2010-2018 годах, не выявил достоверного тренда численности большого пестрого дятла. При этом обилие вида значительно колебалось год от года. С 2010 по 2012 год средняя зимняя плотность большого пестрого дятла росла, достигнув 77 ос./км². За этим последовало резкое снижение средней плотности - до 14 ос./км² зимой 2012-2013 года. В последующие годы численность вида росла, достигнув к 2015-2016 году значения в 117 ос./км². В два следующих зимних сезона обилие большого пестрого дятла снизилось и колебалось в районе 40 ос./км ${ }^{2}$ (рис. 4).

Поскольку основным кормовым ресурсом большого пестрого дятла в зимнее время являются семена ели и сосны [21, с. 284], мы связываем колебания его численности с ежегодными отличиями в урожайности древесных пород - сосны и ели. Это повлияло на особенности его динамики по сравнению с другими видами дятлов на исследованной территории.

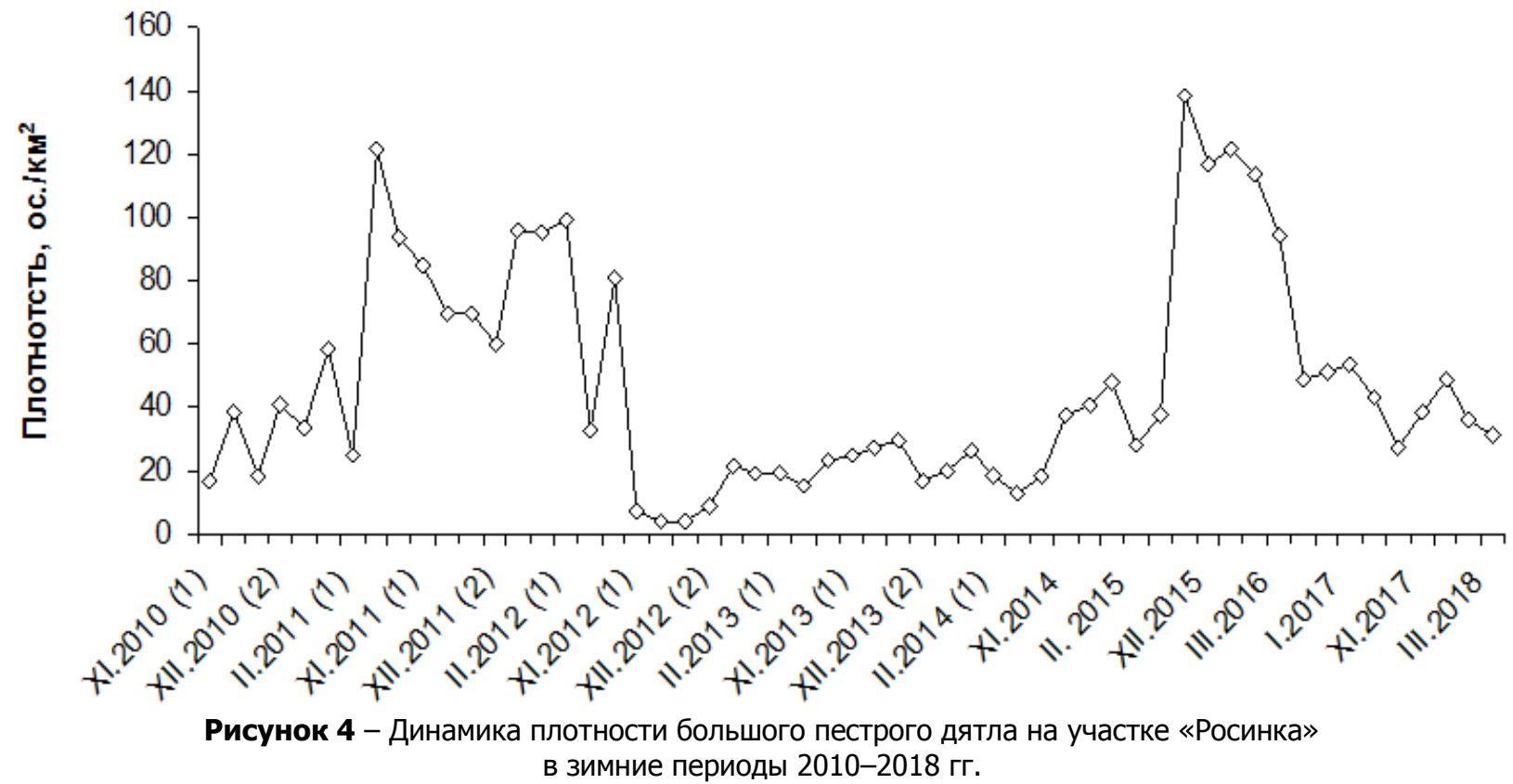

Сравним наши данные с результатами учетов, проведенных в Заволжье в 1990-х и 2000-х годах [4, c. $285 ; 22$, с. $45-46 ; 23$, с. $17-23]$. Их анализ также показывает, что большой пестрый дятел был более многочислен в урожайные для хвойных пород годы. Однако значения, зафиксированные исследователями в предыдущие годы, значительно ниже наших - особенно в урожайные годы (39 ос./км² против 117 ос./км²). Возможно, на территории региона имеет место долговременная тенденция к росту численности большого пестрого дятла. Это противоречит выводам о снижении численности вида, сделанными по итогам мониторинга в Нижнем Присурье [5, с. 82].

Большой пестрый дятел играл важную роль в формировании зимних орнитокомплексов Заволжья. В 2015-2018 году средняя доля этого вида в общем населении птиц составила на трех исследованных участках 11\%. Наибольшей она была на участке «Росинка»-14\%. Здесь в отдельных учетах доля большого пестрого дятла в общем населении могла доходить до $39 \%$.

Белоспинный дятел (Dendrocopos leucotos Bechstein, 1802). В Чувашской Республике - малочисленный гнездящийся оседлый вид $[15$, с. 68$]$. Единственный учет численности в Чувашском Заволжье относится к июню 2001 года, когда в смешанных лесах Заволжья была отмечена плотность 1,1 ос./км² [4, c. 289].
Согласно нашим наблюдениям, белоспинный дятел в Чувашском Заволжье относится к редким оседлым видам. За период исследований он отмечен нами 7 раз. Встречи были приурочены к двум маршрутам, расположенным у реки Волга; часть встреч происходила на границе пойменного леса. На участке «Сосновка» вид отмечался в январе и ноябре 2015 года, а также в марте 2018 года. Его плотность колебалась от 1 до 4 ос./км². На участке «Росинка» вид отмечался 4 раза: в ноябре 2013 и 2014 года, а также в январе и декабре 2015 года. Минимальное обилие составило 1 ос./км², максимальное - 6 ос./км². На участке «Ландыш», наиболее удаленном от поймы Волги, вид не отмечался. Относительная редкость вида в Заволжье связана с тем, что он предпочитает хвойным лесам лиственные и смешанные [2, с. 344]. Несмотря на это, его обилие здесь было выше, чем в хвойных лесах заповедника «Присурский» (где зимой 20022003 года была отмечена плотность 0,3 ос./км²) и сосняках национального парка «Чӑваш вӑрманӗ» (зимой 2006-2007 года плотность белоспинного дятла составила здесь 0,4 ос./км²) [4, с. 290].

Малый пестрый дятел (Dendrocopos minor Linnaeus, 1758). Обычный гнездящийся оседлый вид Чувашской Республики [15, с. 68]. Последняя по времени оценка численности в Заволжье относится к зиме 2001-2002 года, когда была отмечена плотность в 2,6 ос. $/ \mathrm{Kм}^{2}$ [4, с. 292]. 
Согласно нашим наблюдениям, в зимний период малый пестрый дятел относился к малочисленным видам Чувашского Заволжья. Чаще всего он отмечался в составе смешанных синичьих стай. На участке «Ландыш» малый пестрый дятел был отмечен нами 6 раз. Средняя плотность вида здесь составила 2 ос./км². Максимальное обилие было зафиксировано в январе 2016 года $(10$ ос./км²). На участке «Сосновка» численность вида была сходной: плотность колебалась от 1 до $11 \mathrm{oc} / \mathrm{KM}^{2}$, а ее среднее значение в зимние сезоны 2014-2018 годов составило 2 ос./км².

На участке «Росинка» малый пестрый дятел встречался чаще, однако его средняя плотность была ниже $(1$ ос./км²). Причина в том, что в первые две зимы исследований вид не отмечался на данном маршруте. В зимний период 2012-2013 годов малый пестрый дятел стал обычным видом на исследованной территории: отмечался практически в каждом учете, а его средняя плотность составила 3 ос./ $/ \mathrm{\kappa m}^{2}$. Зимой 2013-2014 года средняя плотность составила 4 ос./км². Однако уже в зимний период 20142015 года вид отмечался только трижды, с ноября по январь, а его плотность снизилась до 1 ос./км². В последующие зимы малый пестрый дятел регистрировался 1-2 раза за сезон, а его среднее обилие не превышало 1 ос./км². Как следствие, достоверный тренд численности за указанный период выявить не удалось $(\mathrm{r}=0,1 ; \mathrm{p}=0,52)$.

Подобная динамика численности на участке «Росинка» немного напоминает ту, что была характера для трехпалого дятла и желны (рис. 3). Возможно, рост плотности малого пестрого дятла также связан с пожарами и усыханием деревьев, а ее дальнейшее снижение - с санитарными рубками. Средняя зимняя плотность малого пестрого дятла и желны взаимно коррелировали (см. выше).

Сравнение с литературными данными показывает, что с 2001-2002 года зимняя численность вида в Заволжье в целом оставалась стабильной. Сходные значения были отмечены в 1989-1999 года во время зимних учетов в Присурье (Шумерлинский район Чувашской Республики). Здесь малый пестрый дятел отмечался нерегулярно, а его плотность колебалась от 1,5 до 3 ос./км² [4, с. 292].

Трехпалый дятел (Picoides tridactylus Linnaeus, 1758). Редкий гнездящийся оседлый вид хвойных лесов [15, с. 68]. Трехпалый дятел занесен в Красную книгу Чувашской Республики как вид, находящийся под угрозой исчезновения (1 категория) [16, с. 239 240]. Издание «Птицы Чувашии» упоминает о 5 встречах этого вида на территории Заволжья в зимний период: в 1998, 2000, 2006, 2007 и 2014 годах [4, c. 294]. Помимо Заволжья, трехпалый дятел в Чувашии также отмечался в Присурье, национальном парке «Чӑваш вӑрманӗ» и во время кочевок в лиственных лесах правобережья Волги.

В ходе зимних учетов 2010-2018 годов мы 12 раз отмечали трехпалых дятлов в Заволжье (часть этих встреч упоминается в работе О.В. Аськеева и др. [24, c. 12]). По нашим данным, на исследованной территории вид относится к очень редким. В зимний период он был отмечен на двух учетных маршрутах из трех. На участке «Ландыш» нами зарегистрирована единственная встреча - 1 особь 13.12.2015. На маршруте «Росинка» трехпалый дятел был более много- численным - вероятно, в связи с обилием сухостойных деревьев. В зимние периоды 2010-2012 годов вид здесь нами не отмечался, однако с ноября 2012 по март 2013 года было зафиксировано 3 встречи, а средняя плотность составила 0,6 ос./км². Зимой 2013-2014 и 2014-2015 годов вид был обычен и регистрировался регулярно. Его среднее обилие было равно соответственно 1 и 2 ос./км ${ }^{2}$. Максимальная отмеченная плотность составила 7 ос./км².

Как и в случае с желной, мы связываем данную динамику численности трехпалого дятла с пожарами и засухой лета 2010 года. В результате аномально жаркой погоды около трети лесного покрова Заволжья было уничтожено пожарами, а в сохранившейся части значительное количество деревьев погибло. Мертвые и усыхающие деревья обеспечили кормовую базу для насекомых-ксилофагов, на питании которыми, в свою очередь, специализируется трехпалый дятел [25, с. 222-226]. Это привело к увеличению численности вида на горельниках и на исследованной территории, хотя сложно сказать, результат ли это прикочевки из других регионов или удачного размножения местных гнездовых пар. Учитывая двухлетнюю задержку между пожарами и вспышкой численности вида, можно исключить предположение, что птицы мигрировали на данный участок из-за разрушения их естественной среды обитания вследствие пожаров. Мы полагаем, что высокое обилие в Заволжье в 2013-2015 годах обусловило встречи трехпалого дятла на территории нагорных дубрав Чувашии 06.03.2014 и 11.03.2015 [4, с. 294]. Авторы монографии «Птицы Чувашии» связывают эти регистрации с послегнездовыми кочевками, однако, на наш взгляд, здесь мог иметь место элемент тенденции к расселению.

Однако благоприятные условия для трехпалого дятла продолжались недолго. К лету 2015 года обширные площади горельников северного Заволжья были очищены от сухостоя, а большинство мертвых деревьев на исследуемой территории было повалено ветром или удалено в ходе санитарных рубок. В результате начиная с зимы 2015-2016 года вид перестал отмечаться на исследуемой территории до конца периода наблюдений. Можно предположить, что его обилие в Заволжье снизилось до значений, характерных для периода до пожаров, а возможно, в связи с масштабными санитарными рубками, и еще ниже.

\section{Выводы}

Наши исследования показали, что на территории Чувашского Заволжья представлено высокое разнообразие дятлов. Из 9 видов, зарегистрированных в регионе, здесь нами отмечены 6. Наибольшее число видов было характерно для участков с более высоким разнообразием растительности и большим количеством сухостоя. При этом статус различных видов дятлов в Заволжье значительно различался между собой. В то время как большой пестрый дятел был многочисленным видом, доминирующим по численности в орнитокомплексах, а желна - обычным, другие дятлы встречались намного реже.

Большинство отмеченных видов не демонстрировали достоверных трендов численности, исключением была лишь желна, обилие которой росло. Тем не менее численность многих видов значительно коле- 
балась год от года. На наш взгляд, причиной этого послужили такие факторы среды, как урожайность хвойных деревьев и лесные пожары. Три вида (желна, трехпалый дятел и малый пестрый дятел) демонстрировали сходные изменения численности, однако достоверная корреляция численности была отмечена только для двух из них (желны и малого пестрого дятла).

Наши наблюдения частично подтверждают имеющиеся литературные данные. Однако более длинные ряды учетов позволяют нам точнее судить о зимней численности дятлов в Чувашском Заволжье и ее трендах. Для многих видов оценка зимней плотности на данной территории проведена впервые, для других - впервые после длительного перерыва. Полученные нами оценки численности в основном совпадают с приведенными в литературных источниках или превышают их.

Мы надеемся, что наши данные не только позволят расширить научные представления о дятлообразных Чувашской Республики, но и послужат практическим целям охраны редких видов и управления лесами. В частности, учитывая важность сухостойных деревьев для трехпалого дятла и желны, в целях их охраны следовало бы частично ограничить санитарные рубки в Заволжье.

\section{Список литературы:}

1. Virkkala R. Why study woodpeckers? The significance of woodpeckers in forest ecosystems // Annales Zoologici Fennici. Finnish Zoological and Botanical Publishing Board, 2006. C. 82-85.

2. Рябицев В.К. Птицы Урала, Приуралья и Западной Сибири: справочник-определитель. Екатеринбург: Изд-во Урал. ун-та, 2001. 608 с.

3. Птицы России и сопредельных регионов: Coвообразные, Козодоеобразные, Стрижеобразные, Ракшеобразные, Удодообразные, Дятлообразные / В.Т. Бутьев [и др.]. М.: Т-во научных изданий КМК, 2005.487 с.

4. Птицы Чувашии. Неворобьиные. Т. 2 / О.В. Глушенков, Г.Н. Исаков, А.А. Яковлев, В.А. Яковлев; науч. ред. Г.Н. Исаков. Чебоксары: Чуваш. кн. издво, 2017. $311 \mathrm{c}$.

5. Преображенская Е.С., Глушенков О.В. Итоги мониторинга зимней численности птиц в Нижнем Присурье // Nature Conservation Research. Заповедная наука. 2016. № 1 (1). С. 78-97.

6. Краснов Н.А. О деградации лесов Чувашского Заволжья // Роль ботанических садов и дендропарков в импортозамещении растительной продукции: I всерос. науч.-практ. конф. с междунар. участием, посв. 50-летию создания Общественного совета по организации Чебоксарского ботанического сада. Чебоксары, 2016. С. 79-80.

7. Физико-географическое районирование Среднего Поволжья / под ред. А.В. Ступишина. Казань: Изд-во Казанск. гос. ун-та, 1964. 198 с.

8. Димитриев А.Д., Димитриев А.В., Глебов В.П. Проект организации и развития природного парка «Заволжье». Т. 2. Чебоксары, 1996. 81 с.

9. Курбанов Э.А., Воробьев О.Н., Лежнин С.А., Полевщикова Ю.А. Оценка лесных гарей Чувашии методами дистанционного зондирования // Вестник ИрГСХА. 2013. № 54. С. 80-87.
10. Фомич А.Ф., Смышляева М.И., Краснов В.Г. Анализ технологий лесовосстановления горельников на территории Чебоксарского лесничества Чувашской Республики // Актуальные направления научных исследований XXI века: теория и практика. 2014. T. 2, № 5-3. С. 79-83.

11. Постановление кабинета министров Чувашской республики от 24.08.2017 г. № 336 «О создании государственного природного заказника регионального значения "Заволжский"».

12. Равкин Ю.С. К методике учета птиц лесных ландшафтов // Природа очагов клещевого энцефалита на Алтае. Новосибирск: Наука, 1967. С. 66-75.

13. Коблик Е.А., Редькин Я.А., Архипов В.Ю. Список птиц Российской Федерации. М.: Товарищество научных изданий КМК, 2006. 256 с.

14. Калашникова О.А. О встрече среднего пестрого дятла в Чувашии // Орнитология. Вып. 32. М., 2005. C. 123.

15. Яковлев А.А., Яковлев В.А. Список птиц Чувашской Республики // Естественнонаучные исследования в Чувашии: материалы докладов региональной науч.-практ. конф. (г. Чебоксары, 19 ноября 2015 г.). Чебоксары: рекламно-полиграфическое бюро «Плакат», 2015. Вып. 2. С. 58-75.

16. Красная книга Чувашской Республики. Т. 1. Ч. 2. Редкие и исчезающие виды животных. Чебоксары: ГУП «ИПК «Чувашия», 2010. 372 с.

17. Результаты зимних учетов птиц в Европейской части России и сопредельных регионов. Вып. 14-15. Зимние сезоны 1999/2000 и 2000/2001 гг. M., 2003. 66 c.

18. Результаты зимних учетов птиц в Европейской части России и сопредельных регионов. Вып. 16-17. Зимние сезоны 2001/2002 и 2002/2003 гг. M., 2003. 64 c.

19. Результаты зимних учетов птиц в Европейской части России и сопредельных регионов. Вып. 21. Зимний сезон 2006/2007 г. М., 2007. 51 с.

20. Результаты зимних учетов птиц в Европейской части России и сопредельных регионов. Вып. 22. Зимний сезон 2007/2008 г. М., 2009. 52 с.

21. Птицы Волжско-Камского края: Воробьиные / отв. ред. В.А. Попов. М.: Наука, 1977. 296 с.

22. Результаты зимних учетов птиц в Европейской части России и сопредельных регионов. Вып. 89. Зимние сезоны 1993/1994 и 1994/1995 гг. М., 1996. $60 \mathrm{c}$.

23. Глушенков О.В. Структура и динамика зимнего населения птиц различных типов леса Нижнего Присурья // Научные труды государственного природного заповедника «Присурский». Чебоксары Атрать, 2001. Т. 4. С. 16-24.

24. Аськеев О.В., Аськеев И.В., Аськеев А.О., Коленов С.Е. Материалы к изучению редких и исчезающих видов птиц ряда ООПТ Чувашской Республики и Республики Татарстан // Научные труды Государственного природного заповедника «Присурский». 2015. Т. 30, № 1. С. 11-16.

25. Hogstad O. et al. On the ecology of the Threetoed Woodpecker Picoides tridactylus (L.) outside the breeding season // Nytt Magasin for Zoologi. 1970. T. 18. C. 221-227. 


\title{
DIVERSITY AND NUMBER OF WOODPECKERS (PICIDAE) IN THE CHUVASH TRANS-VOLGA REGION IN WINTER
}

\author{
(C) 2018
}

Kolenov Sergei Evgenievich, postgraduate student, engineer of Zoology and General Biology Department Kazan (Volga Region) Federal University (Kazan, Russian Federation)

\begin{abstract}
This article gives some data on the winter fauna of woodpeckers (Picidae) in the Trans-Volga Region of the Chuvash Republic. We analyze the species richness, their number and trends of its changes. To do it, it is possible when the reserachers analyze the results of the collected materials of 2010-2018 (on the example of three routes during ornithological surveys according Y.S. Ravkin's method). The author believes that the importance of work is to show the lack of surveys concerning the analysis of winter fauna of woodpeckers in the Chuvash Trans-Volga Region. Moreover it shows to determine what impact on the avifauna of the Transvolga was caused by destructive fires in the summer of 2010 (as it destroyed up to $30 \%$ of the forest cover of the investigated territory). The article presents that the Chuvash Trans-Volga Region is inhabited by 6 species of woodpeckers out of 9, named in the Chuvash Republic. A great spotted woodpecker was a numerous and dominant species, black woodpecker was ordinary species, and the rest were less common. The greatest variety of woodpeckers was noted on the route with the maximum variety of vegetation and plenty of dead wood. A reliable positive population trend was revealed for the black woodpecker. The population of the great spotted woodpecker as a whole remained stable although it showed considerable fluctuations from year to year, depending on the yield of coniferous trees. For other species, it was not possible to identify any long-term trend. Three species of woodpeckers (the black, the lesser spotted and the three-toed woodpeckers) demonstrated mutual changes of the average winter density. All these species showed a significant increase in numbers, which gave a way to a decline then. We believe that the growth in numbers was due to the fires and drought of 2010, which provoked an outbreak of xylophagous insects and fodder base of these species. The subsequent clearing of the burners and the sanitary cutting reduced the food resources available for insects, what decrease the number of woodpeckers. We believe that sanitary cuttings should be abandoned in some areas of the Trans-Volga Region to preserve these species.

Keywords: woodpeckers; Piciformes; great spotted woodpecker; black woodpecker; three-toed woodpecker; lesser spotted woodpecker; grey-headed woodpecker; white-backed woodpecker; green woodpecker; middle spotted woodpecker; wryneck; winter population of birds; dynamics of number of birds; ecology; coniferous forests; Chuvash Republic; Cheboksary district; Volga Region; Chuvash Trans-Volga Region; wildfires.
\end{abstract}

УДК 582.263, 574.34, 582.293.346

Статья поступила в редакцию 02.07.2018

\section{ВИДОВОЕ РАЗНООБРАЗИЕ И ОСОБЕННОСТИ ЛОКАЛИЗАЦИИ ФОТОБИОНТА В ЭПИГЕЙНЫХ ЛИШАЙНИКАХ РОДА CLADONIA}

(C) 2018

Корчиков Евгений Сергеевич, кандидат биологических наук, доцент кафедры экологии, ботаники и охраны природы

Болгов Егор Владимирович, студент биологического факультета

Ильина Елена Сергеевна, студент биологического факультета

Самарский национальный исследовательский университет имени академика С.П. Королёва

(2. Самара, Российская Федераиия)

Панкратов Тимофей Анатольевич, кандидат биологических наук, руководитель проекта, кафедра биологии почв

Московский государственный университет им. М.В. Ломоносова (2. Москва, Российская Федерация)

Аннотаиия. В данной статье рассматривается таксономический состав и особенности локализации фотобионтов в кустистых эпигейных лишайниках рода Cladonia. Описываются количество и видовая принадлежность клеток водорослей в гомогенатах талломов в зависимости от их возраста: в зонах активного роста, старения и разложения, а также в смывах с талломов. Рассматривается влияние микобионта на видовой состав и численность фотобионта. Приводится сравнение этих данных в лишайниках северотаёжной зоны (Мурманская область) и степной зоны (Оренбургская область). Определение таксономической принадлежности фотобионтов к роду определяли методом прямой микроскопии с использованием морфологических критериев: размер, форма клеток, характер хроматофора и т.п. Численность фотобионта в образцах исследовали как методом световой микроскопии, так и с помощью флуоресцентной микроскопии. В работе представлены результаты сравнения численности и разнообразия водорослей в талломах эпигейных лишайников рода Cladonia в зависимости от их географической локализации и характера возрастной динамики подециев. Проведённые исследования показали, что доминирующими группами в активно растущих подециях лишайников были представители рода Asterochloris вне зависимости от их географической локализации. В лишайниках обнаружены представители родов Chlorella, Stichococcus, Pseudococcomyха. Новыми для науки оказались сведения об изменении таксономического состава водорослей в зависимости от возраста таллома: в старых частях северотаёжных лишайников доминировали водоросли Pseudococcomyха, а в степных - Stichococcus. Сделана попытка ресинтеза лишайникового таллома из ранее изолированных культур микобионта и фотобионта. На данном этапе исследований она оказалась неудачной. 